\title{
What can business model innovation bring to transport service operations in a context of increasing liberalization
}

\author{
Mateu, Jose M. \\ Lecturer, Universidad Politécnica de Valencia, Spain
}

\begin{abstract}
Transport services continue to be liberalized across the entire European Union, although at differing speeds in each Member State. This momentum is expected to continue in the coming years.
\end{abstract}

Against this background, attention to new dimensions of transport services becomes imperative. The focus, which has so far centred on managing infrastructure, must now shift to lesser explored areas, like product innovation and customer relationship management. The efficiency and competitiveness of new private operators will depend to a large extent on achieving a balanced development of the three aforementioned areas, as well as paying particular attention to their inherent logic, in order to build a strong value proposition.

Business model innovation emerged in the field of strategic management yet goes beyond the traditional framework of competition 'for the market' and 'in the market', opening a wider and more promising space, i.e. the market creation framework. The goal is no longer to discover and exploit opportunities, but to create new opportunities and generate new market spaces.

\section{INTRODUCTION}

Strategic management is a well-established field of knowledge and has built a strong paradigm over more than sixty years of research thanks to focusing on free competition between companies. It is also a living science that continues to grow in strength, bringing beneficial results. Business model innovation, in particular, has provided a solid explanation of the competitive advantage certain companies have and why they are at the forefront of their markets. More than this, the business model innovation concept explains how a small number of companies have been able to create new markets.

The liberalization of the transport market gives us the opportunity to apply the latest trends in strategic management to this industry. The main goal of this paper to showcase the vast array of possibilities afforded by the application of these trends. For example, some authors propose the emergence of the low-cost model in the aviation industry as a clear case of business model innovation. 
There may well be a significant volume of opportunities waiting to be discovered or created, both in the freight transport industry as well as in passenger transport. This paper points to ways to detect, generate and take advantage of these potentialities.

\section{WHAT STRATEGIC MANAGEMENT ADVANCES COULD BE ADDED TO THE RECENTLY LIBERALIZED TRANSPORT MARKETS?}

\subsection{Business dimensions}

Several EU directives have clearly established the unbundling of infrastructure activities and transport operations. However, this separation does not seem to be sufficient to address the main problem, namely the competitiveness of the businesses entering the newly liberalized market. Several recent research works have highlighted this problem in different transport modes (Aarhaug and Fearnley, 2016; Cantos, Pastor, and Serrano, 2012; Nilsson et al., 2013; White and Robbins, 2012). More specifically, Bošković and Bugarinović (2015) cited the fact that "the problem of performance management has not been treated" (Bošković and Bugarinović, 2015, pg. 51), and López Pelaez et al. (2012) believe that "it is necessary to analyze 'organization aspects' as part of the technology concept" (Lopez Pelaez, Segado Sanchez-Cabezudo, and Kyriakou, 2012, pg. 1388).

Hagel and Singer (1999) found three types of business beneath the surface of most companies: the infrastructure business, the product innovation business and the customer relationship business. "They each play a unique role; they each employ different types of people; and they each have different economic, competitive, and even cultural imperatives" (Hagel and Singer, 1999, pg. 134; see Table 1).

\begin{tabular}{|c|c|c|c|}
\hline & $\begin{array}{l}\text { Infrastructure } \\
\text { business }\end{array}$ & $\begin{array}{c}\text { Product innovation } \\
\text { business }\end{array}$ & $\begin{array}{l}\text { Customer } \\
\text { relationship business }\end{array}$ \\
\hline Economics & $\begin{array}{l}\text { Large volume to } \\
\text { achieve low unit } \\
\text { costs. Economies of } \\
\text { scale are key }\end{array}$ & $\begin{array}{l}\text { Early market entry for } \\
\text { premium prices and } \\
\text { large market shares }\end{array}$ & $\begin{array}{l}\text { Customer care to gain } \\
\text { their loyalty and } \\
\text { maximize their share } \\
\text { of wallet }\end{array}$ \\
\hline Culture & $\begin{array}{l}\text { Cost focused, stress } \\
\text { on standardization, } \\
\text { predictability, } \\
\text { efficiency }\end{array}$ & $\begin{array}{l}\text { Employee-centred to } \\
\text { attract and develop } \\
\text { 'stars' }\end{array}$ & $\begin{array}{l}\text { Customer- and } \\
\text { service-oriented }\end{array}$ \\
\hline Competition & Battle for scale & Battle for talent & Battle for scope \\
\hline
\end{tabular}

Table 1 - Unbundling the corporation (adapted from Hagel and Singer, 1999) 
Our transport infrastructures have improved significantly over the last decades, thanks to the input of public resources, the protection of monopolistic markets and the technical search for efficiency. Hence, "transport companies focus largely on reducing their costs and have lower incentives to invest in R\&D" (Wiesenthal, Condeço-Melhorado, and Leduc, 2015, pg. 88). However, these driving principles may not be suitable to manage operations in a liberalized market. Economies of scale and a cost-focused mentality drive infrastructure businesses, but this is not the case for either product innovation or customer relationship businesses. The latter is driven by scope and a customer-oriented mentality, whilst creativity, time-to-market and the battle for talent are the main keys in the product innovation business arena.

When it comes to competing in a liberalized operational market, these last two perspectives become relevant, and a traditional cost and scale focus can be adverse. A magnitude of dimensions are relevant in transport development (Xie and Levinson, 2009), but the managerial dimension is the factor that becomes the catalyst for change. Transport operation management in a competitive context requires attention to these different perspectives, as well as changes in how we conceptualize and manage them.

\subsection{From 'competition for the market' to 'competition in the market' and beyond}

Since the first moves towards liberalization, company focus has centred on seizing the new opportunities created by the liberalization process. This has materialized in both 'competition for the market' and 'competition in the market'. These are both important areas for competition, but they do not cover all the spaces for opportunity.

When companies bet 'for the market', they try to make a profit from an opportunity defined by a public entity. When they compete in a liberalized market, they usually bet for the consumers traditionally included in that market. Kim and Mauborgne (2005) showed how certain companies are able to create new market spaces through innovation. They named these spaces 'blue oceans', as opposed to 'red oceans', i.e. oceans filled with blood as a result of fierce competition between several established competitors in a mature market (Kim and Mauborgne, 2005).

Innovation thus becomes the lever, the tool able to generate new markets and create new market space, of which the competition is unaware. This new market space will end up being 'dyed red' over time but, until this happens, the pioneers will benefit from valuable competitive advantages. If they are clever at managing these advantages, they will be able to consolidate their leadership.

The challenge is to build a new scenario (Alvarez, Barney, and Anderson, 2013) and to meet this challenge, "all-important innovations will probably not be those that affect the transport vehicle but rather the system in which it is incorporated" (Crozet, 2010), pg. 20). However, 
only "radical and disruptive innovations have the power to change the market structure and create new business practices and/or markets" (Wiesenthal et al., 2011), pg. 43). Therefore, we are talking about 'architectural innovation' (Henderson and Clark, 1990) which can introduce 'disruptive business concepts' (Assink, 2006) that change transport systems in their entirety. Business model innovation is the conceptualization put forward by strategic management for this kind of innovation.

\subsection{Business model innovation}

Magretta (2002) described business models as "stories that explain how enterprises work", and added, "a good business model answers Peter Drucker's age-old questions: Who is the customer? And what does the customer value? It also answers the fundamental questions every manager must ask: How do we make money in this business? What is the underlying economic logic that explains how we can deliver value to customers at an appropriate cost?" (Magretta, 2002).

The concept has received growing attention during the last decade because it explains the success of a large number of internationally well-known companies, such as Ikea, Dell, Le Cirque du Soleil and, in our field, low cost airlines. Furthermore, expectations for the future are even greater: "... a company has at least as much value to gain from developing an innovative new business model as from developing an innovative new technology" (Chesbrough, 2010).

Although there is no commonly accepted definition, a business model can be conceptualized by its components. Figure 1 shows the set of components proposed by Lindgart et al. (2009).

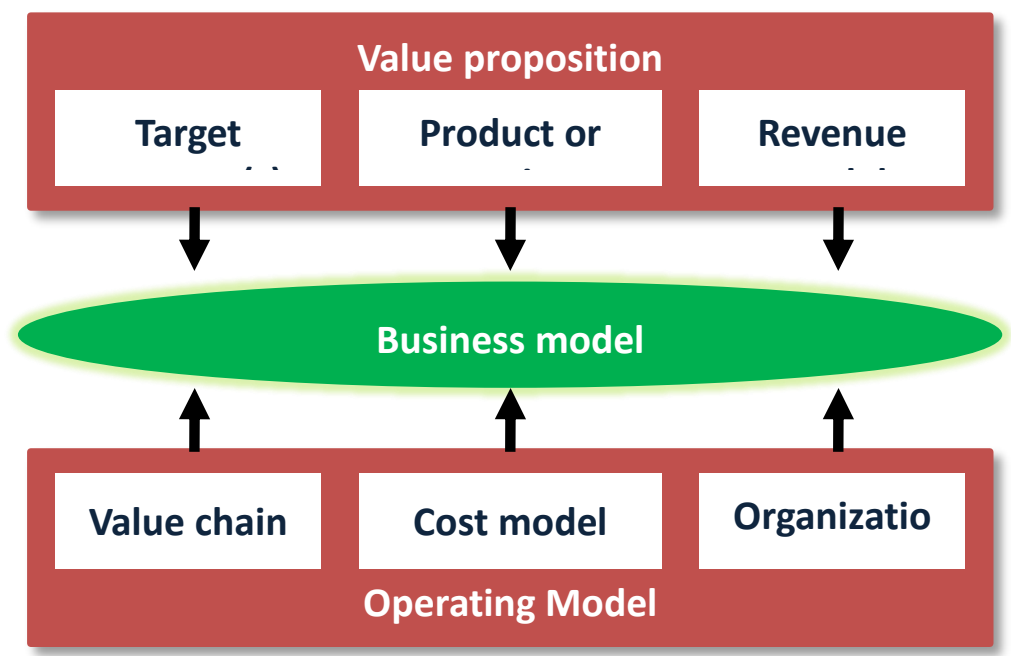

Figure 1.- Business model representation (Lindgardt et al., 2009)

In any case, it is the introduction of a new business model that can change the market 
structure. Therefore, business model innovation is the key.

These authors also proposed a useful definition for business model innovation: "innovation becomes business model innovation when two or more elements of a business model are reinvented to deliver value in a new way". This definition implies more disruptive innovation, in the meaning highlighted by Christensen (1997), and can lead to greater changes in an overall business model. It is not enough to make a small change in a component of the model. Radical change will force the reorganization of the overall model in order to obtain the otherwise required consistency. And it is this requirement that makes companies reluctant to develop and adopt new business models. It is difficult to introduce changes that affect entire systems in companies trapped by inertia (Pardo del Val and Martínez Fuertes, 2003).

\subsection{Business model innovation in the transport field}

Each company competing in a market has an explicit or implicit business model. Different business models compete for the same or alternative market segments. Legacy airlines, for instance, use a traditional business model based on 'hub and spoke' networks, multiclass services and premium fares. They face competition from low-cost carriers, and regional and charter airlines. On a specific route, the competition may be other airlines using other models, like the shuttle business model for example.

Strategy management research has proposed the emergence of low-cost aviation as a paradigmatic example of business model innovation (Casadesus-Masanell and Enric Ricart, 2010). The innovative business model developed by Southwest Airlines in the seventies reshaped the entire airline industry and created new customer categories (only one in three low-cost aviation passengers also travelled with other types of airlines). This may mean that some routes, and even regions, may not be served until an innovative company is able to articulate a useful business model. It is pertinent to add here that low-cost aviation in Europe was only able to emerge when the European air market was truly liberalized.

Two other remarkable examples of business model innovation can be found in the cargo transport industry. These were the introduction of the container in the late fifties and the emergence of integrated carriers in the air cargo industry. The success of the innovation created by Malcolm McLean is in some ways surprising, particularly if we look at its lack of high technology. Yet the container radically changed the cargo transport industry, making 'door to door' transportation possible. In any case, it was not solely a question of putting products in a box. The entire system was turned on its head, from procedures and vehicles, through to staff mentality.

The story of express or integrated carriers in the air cargo market is also significant. The new model was introduced during the seventies by UPS, and successfully followed by others like 
DHL and FedEx. It is based on all-cargo aircrafts, sorting hubs and spokes networks, delivery vehicles, advanced information systems and the management of this comprehensive system by a sole organization. The result of this integrated operating model is a strong value proposition, materialized in fast, safe parcel delivery, at a competitive price.

\subsection{In search of new business models}

Although the conceptualization of business models and the study of business model innovation are recent, the huge opportunities afforded have sparked a vigorous movement that seeks to harness their potential. New methods aiming to innovate business models have emerged. Some examples of these include experimentation (McGrath, 2010), systematic deconstruction/unpacking of existing business models (Teece, 2010), decomposition in different groups of choices (Casadesus-Masanell and Enric Ricart, 2010), introduction of changes that rebuild the market's boundaries (Kim and Mauborgne, 2005) aggregation in order to see the larger picture without getting lost in the details (Casadesus-Masanell and Enric Ricart, 2010), ideation, prototyping, and story-telling (Osterwalder and Pigneur, 2010).

On another level, the transfer of successful business models from one market to another or from one industry to another has been less imaginative yet can be considered useful. Accordingly, Ryanair, Easyjet and dozens of other companies copied Southwest's model so they could introduce it into Europe. Now, years later, Easygroup has rolled out the low cost model to more than a dozen different industries such as coach transportation (easyBus), hotels (easyHotel), food stores (easyFoodstore), and office rental (easyOffice).

\subsection{An illustrative example of implementation}

We shall now focus our creative capacity on the optimization of combined road and rail transport, as an illustration. Trucks and trailers can be loaded onto railroad cars, as though the latter were Ro-ro ferries in the case of combined sea-land transport. There are different technical solutions available to facilitate the loading of these units onto rail platforms such as low-loaders in the case of 'rolling motorway', driving trucks directly onto connecting bogies, or Modalohr railroad cars. The technical solution also requires well developed transport terminals, though it should be stressed that a well-chosen technical solution is no guarantee of success. To attract potential customers we must provide a comprehensive, convenient and economical solution.

How should we organize the service to offer a comprehensive solution to the customer? There are several decisions to be made. For example, does the customer prefer to hire truck drivers at the end destination or does he prefer drivers to travel with their trucks? In the latter case, a special sleeping car should be added so drivers can rest during the trip. Should the customer prefer to hire drivers at the end destination, this complementary service can be 
provided, either directly or in conjunction with a local partner. The same can be done with other services, such as customs clearance, or unloading at destination. Service management must therefore address the global solution, door to door, with efficient partners. There is a broad of range of options available. A correct choice requires in-depth knowledge of the needs and wants of the customers (customer relationship management) and the ability to shape a strong value proposal (product innovation management).

\section{CONCLUSION}

Spain liberalized its rail freight market in 2003. At 31st December 2013, six private operators provided services, and licences for another thirteen operators were being processed. According to data published by the Spanish Government, only $14.3 \%$ of freight trains running on the public rail network in 2013 were handled by these private operators (Gobierno de España, 2014). A look at their web sites reveals that they focus on the 'block train' model, a model that is only useful for large customers. This may explain why the incumbent public operator (RENFE-Operadora) retains $85.7 \%$ of the market, providing services based on other models (mainly container block trains).

However, what is striking in the Spanish case is the share of rail transport as a percentage of the total domestic freight market, at just 5.3\%. In Europe, the figure is $18.2 \%$ on average, and only Greece and Ireland are below the Spanish rate (Eurostat, 2013). Increasing this market share will require the adoption of other business models that can attract customers who do not have enough volume of goods to fill entire trains. Applying the concepts and tools of business model innovation to the rail freight market could create this opportunity and show how to exploit it.

The allocation of a specific railway infrastructure capacity to several operators could lead to stiff competition if all of them apply the same business model, but it could also lead to useful implicit cooperation (coopetition) if they apply different business models (traditional scheduled model, low-cost model, shuttle model, or others developed using creative tools), in search of different customer profiles. Product innovation management and customer relationship management must be implemented from a systemic perspective, bearing in mind their respective economic, competitive, and even cultural imperatives.

\section{REFERENCES}

AARHAUG, J., and FEARNLEY, N. (2016). Deregulation of the Norwegian long distance express coach market. Transport Policy 46(7), pp. 1-6.

ALVAREZ, S.A., BARNEY, J.B. and ANDERSON, P. (2013). Forming and Exploiting Opportunities: The Implications of Discovery and Creation Processes for Entrepreneurial and Organizational Research. Organization Science 24(1), pp. 301-317. 
ASSINK, M. (2006). Inhibitors of disruptive innovation capability: a conceptual model. European Journal of Innovation Management 9(2), pp. 215-233.

BOSKOVIC, B. and BUGARINOVIC, M. (2015). Why and how to manage the process of liberalization of a regional railway market: South-Eastern European case study. Transport Policy 41, pp. 50-59.

CANTOS, P., PASTOR, J.M. and SERRANO, L. (2012). Evaluating European railway deregulation using different approaches. Transport Policy 24. pp. 67-72.

CASADESUS-MASANELL, R. and RICART, J.E. (2010). From Strategy to Business Models and onto Tactics. Long Range Planning 43, pp. 195-215.

CHESBROUGH, H. 2010. Business Model Innovation: Opportunities and Barriers. Long Range Planning 43(2-3), pp. 354-363.

CHRISTENSEN, C.M. (1997). The innovator's dilemma: when new technologies cause great firms to fail. Boston: Harvard Business School Press.

CROZET, Y. (2010). Driving forces of innovation in the transport sector. Transport and innovation. Unleashing the potential.

EUROSTAT (2013). Freight transport statistics - Modal split.

GOBIERNO DE ESPAÑA, Ministerio de Fomento (2014). Observatorio del Ferrocarril en España. Informe 2013.

HAGEL, J., and SINGER, M. (1999). Unbundling the corporation. Harvard Business Review 77(2), pp. 133-141.

HENDERSON, R.M. and CLARK, K.B. (1990). Architectural innovation - The reconfiguration of existing product technologies and the failure of established firms. Administrative Science Quarterly 35(1), pp. 9-30.

KIM, W.C. and MAUBORGNE, R. (2005). Blue Ocean Strategy. Harvard Business School Press. Boston.

LINDGART, Z., REEVES, M., STALK, G. and DEIMLER, M.S. (2009). Business Model Innovation. The Boston Consulting Group.

LÓPEZ, A. SEGADO, S. and KYRIAKOU, D. (2012). Railway transport liberalization in the European Union: Freight, labor and health toward the year 2020 in Spain. Technological Forecasting and Social Change 79(8), pp. 1388-1398.

MAGRETTA, J. (2002). Why business models matter. Harvard Business Review 80(5).

MCGRATH, R.G. (2010). Business Models: A Discovery Driven Approach. Long Range Planning 43 (2-3), pp. 247-261.

NILSSON, J.E., PYDDOKE, R., HULTEN, S. and ALEXANDERSON, G. (2013). The Liberalisation of Railway Passenger Transport in Sweden. Journal of Transport Economics and Policy 47, pp. 307-312.

OSTERWALDER, A. and PIGNEUR, Y. (2010). Business Model Generation. Hoboken, Nueva Jersey: John Wiley \& Sons, Inc.

PARDO DEL VAL, M. and MARTINEZ, C. (2003). Resistance to Change: A Literature Review and Emprirical Study. Management Decision 41(2), pp. 148-155.

TEECE, D.J. (2010). Business Models, Business Strategy and Innovation. Long Range Planning 43(2-3), pp. 172-194.

WHITE, P. and ROBBINS, D. (2012). Long-term development of express coach services in Britain. Research in Transportation Economics 36(9), pp. 30-38.

WIESENTHAL, T. CONDEÇO-MELHORADO, A. and LEDUC, G. (2015). Innovation in the European transport sector: A review. Transport Policy 42(8), pp. 86-93.

WIESENTHAL, T., LEDUC, G., CAZZOLA, P., SCHADE, W. and KOHLER, J. (2011). Mapping innovation in the European transport sector. An assessment of R\&D efforts and priorities, institutional capacities, drivers and barriers to innovation. UE Institute for Prospective Technological Studies. 
XIE, F. and LEVINSON, D. (2009). Modeling the Growth of Transportation Networks: A Comprehensive Review. Networks \& Spatial Economics 9 (3), pp. 291-307. 